\title{
ZYX wt Allele
}

National Cancer Institute

\section{Source}

National Cancer Institute. ZYX wt Allele. NCI Thesaurus. Code C92673.

Human ZYX wild-type allele is located in the vicinity of $7 q 32$ and is approximately $10 \mathrm{~kb}$ in length. This allele, which encodes zyxin protein, plays a role in the modulation of cell adhesion and the morphology and maintenance of the actin cytoskeleton. 